\title{
Positioning through address practice in Finland-Swedish and Sweden-Swedish service encounters
}

\section{Norrby, Catrin}

John Benjamins

2018-08-15

Norrby , C , Wide , C , Nilsson , J \& Lindström , J 2018, Positioning through address

practice in Finland-Swedish and Sweden-Swedish service encounters . in K Beeching , C

Ghezzi \& P Molinelli (eds), Positioning the Self and Others : Linguistic Perspectives .

Pragmatics and Beyond New Series , vol. 292 , John Benjamins , Amsterdam , pp. 19-49 . https://doi.org/10.1075/pb

http://hdl.handle.net/10138/310596

https://doi.org/10.1075/pbns.292.02nor

unspecified

acceptedVersion

Downloaded from Helda, University of Helsinki institutional repository.

This is an electronic reprint of the original article.

This reprint may differ from the original in pagination and typographic detail.

Please cite the original version. 


\title{
Positioning through address practice in Finland-Swedish and Sweden- Swedish service encounters
}

\author{
Catrin Norrby, Camilla Wide, Jenny Nilsson \& Jan Lindström
}

This article is published in Beeching, Kate, Chiara Ghezzi, \& Piera Molinelli (eds.) 2018: Positioning the self and others: Linguistic perspectives. John Benjamins Publishing Company. Pages: 19-49. https:// benjamins.com/ catalog/ pbns.292

This chapter investigates social positioning through the use (or non-use) of address pronouns in Finland-Swedish and Sweden-Swedish service encounters recorded at theatre and event booking venues in Finland and Sweden. The results demonstrate some compelling variation in address practices which can be attributed to participant roles (customer or staff), national variety (Finland-Swedish or Sweden-Swedish), age (younger or older speaker and addressee) and situational factors, such as type of venue and type of transaction, as well as micro-situational aspects which occur during the course of the interaction (complications, problems or topics treated as sensitive). The study highlights that different forms of address cannot be associated a priori with a certain level of formality, but should be interpreted in their micro and macro contexts in order to understand existing cultural norms for appropriate address. (132 words)

Key words: address; pluricentric languages; Swedish; service encounters; interactional linguistics; variational pragmatics

\section{Introduction}

Address practice is a powerful linguistic resource for indexing social relationships between self and others in interaction. In this chapter we compare the use of address pronouns in Sweden Swedish and Finland Swedish service encounters recorded at box offices where customers request or collect tickets and where the staff member's task is to process the customer request. We analyse how address pronouns are utilized by staff and customers to position themselves in the local service encounter context and how the choice of pronouns reflects the wider context of the situation as well as the societies where the encounters take place (Sweden, Finland).

The encounters in our dataset are typically brief (on average 2-3 minutes) and highly routinized - both parties are focused on the successful completion of the transaction. Although the interlocutors are generally strangers and unlikely to form any lasting social relationship, these interactions, 
nevertheless, involve negotiation and mutual attention to the task at hand since the management of interpersonal relationships is important for the successful completion of the service encounter.

A previous study (Norrby et al. 2015a) based on the same data, revealed some unexpected and complex patterns in the address choices of the interlocutors (see section 3). The quantitative differences we found across age groups and national varieties strongly suggest that variation in address practices can be related to strategies for positioning self and other in order to establish and maintain social roles. In this chapter we explore these aspects further through a qualitative microanalysis with a focus on how the participants in the interactions use - or do not use - address pronouns to position themselves in relation to one another. The results demonstrate compelling patterns in address choices which can be linked to socio-cultural norms for language usage involving participant roles, age/generation and national variety as well as the situational context, including factors such as the type of transaction and the physical affordances of the venue.

In order to account for variation in address practices, both in the local interactional context and across the national varieties, we combine insights from interactional linguistics (Ochs, Schegloff \& Thompson 1996, CouperKuhlen \& Selting 2001, Kern \& Selting 2012 for Swedish, see Lindström 2008) and variational pragmatics (Schneider \& Barron 2008, Schneider 2010). Broadly speaking, interactional linguistics is concerned with the analysis of the form and function of linguistic units in their situated interactional context. From this follows that linguistic structures are emergent in interaction rather than fixed decontextualized entities, and that they are a collaborative achievement by all participants rather than the product of a single speaker. Methodologically, interactional linguistics is strongly influenced by Conversation Analysis (CA), and shares its empirical interest in how participants organise social interaction, but adds a linguistic dimension to how this is accomplished. Interactional linguistics also takes great interest in contextualisation and how participants in interaction use "linguistic and paralinguistic features to suggest and evoke interpretative frames which are used by participants to 'construct' a context of interpretation" (Kern \& Selting ibid.).

Variational pragmatics is a theoretical framework which combines insights from pragmatics and sociolinguistics, in that it examines pragmatic variation across geographical and social space in order to determine what impact macro-social factors such as region, social class, age, gender and ethnicity might have on language use. It is related to cross-cultural pragmatics, but in contrast, variational pragmatics does not treat languages/cultures as homogenous wholes, but sets out to explore the pragmatic diversity found within a language/culture. Traditionally, in dialectology, regional varieties are synonymous with sub-national varieties (dialects) of a language within a given nation. In variational pragmatics, 
however, regional variation includes also the complexities of national variation found across pluricentric languages, i.e. languages with more than one national centre (Clyne 1992). To date, few studies take this type of areal pragmatic variation into account ${ }^{1}$ and the present chapter on address practices in Sweden Swedish and Finland Swedish service encounters should be seen as a contribution to this field.

The chapter is organised as follows. In section 2 we provide a brief background to the two national varieties of Swedish and then, in particular, the Swedish address system and its use. In section 3 we present the data and the main quantitative results from Norrby et al. (2015a) before we turn to the qualitative analysis and results in section 4 . Section 5 is devoted to a discussion of the implications of the results both in terms of social positioning and national variation. Finally, we offer some concluding remarks in section 6 .

\section{Background}

Swedish is a pluricentric language, a language which enjoys official status in two nations: as the main language of Sweden and one of two official languages in Finland, alongside Finnish. In Sweden, the vast majority of the population $^{2}$ of about 9.7 million (Statistics Sweden 2015) has Swedish as their first language, and Swedish permeates all aspects of society and public life. In contrast, the Swedish-speaking Finns constitute a minority of 5.3 per cent of the Finnish population of about 5.5 million (Statistics Finland 2015). However, it is a minority with a strong legal, economic and cultural position, as a result of historical circumstances (Liebkind, Moring \& Tandefelt, 2007). Historically, Finland was part of the Swedish kingdom for close to 600 years until 1809 when it was relinquished to the Russian empire as a result of the Swedish-Russian war. Swedish remained the language of public administration and bureaucracy until Finnish slowly replaced it in the decades before Finland gained independence in 1917 (Saari 2012). However, in the Finnish constitution from 1918 Finnish and Swedish were given equal rights as official languages of the new republic. Nevertheless, the difference in numbers means that Finnish dominates in most public arenas in Finland today. The language contact situation in Finland naturally impacts on communicative patterns utilized in Finland Swedish - and in Finnish. However, the pragmatic similarities between Finland Swedish and Finnish

\footnotetext{
${ }^{1}$ Beeching, this volume, however, takes a variational pragmatics approach to look at metacommenting features across British, Canadian and US English and European and Canadian French.

${ }^{2}$ Sweden does not collect official statistics on language, but a recent study on the number of speakers of various languages in Sweden reports that $85 \%$ of the population has Swedish as their first language (Parkvall 2016).
} 
can also be related to cultural and societal preferences that Finland-Swedish and Finnish speakers share as inhabitants of the same country.

\subsection{Address in Sweden Swedish and Finland Swedish}

Similar to many languages, Swedish distinguishes between an informal and a formal pronoun of address in the singular, often referred to as $\mathrm{T}$ and $\mathrm{V}$ pronouns after Latin $t u$ and vos (Brown \& Gilman 1960). Superficially, the Swedish pronominal address system is similar to the French where the second-person plural pronoun (vous in French and $n i$ in Swedish) also functions as a formal pronoun of address to one person. However, contrary to French, addressing somebody by $n i$ is rare in contemporary Swedish, leaving $\mathrm{T}$ address $(d u)$ as the default choice in most contexts and to most interlocutors (Clyne, Norrby \& Warren, 2009: 7).

In Sweden Swedish V address ( $n i$ ) disappeared almost completely following the so-called ' $d u$-reform' in the late 1960s. Despite its name, the ' $d u$-reform' was not an officially sanctioned reform, but the result of a growing resistance to the cumbersome address usage at the time where use of titles and third person address were commonplace. Since the V pronoun had become tainted by its use 'downwards' to a person who lacked a title (Ahlgren 1978, Fremer 2015) this resulted in avoidance of $n i$ in order not to offend the addressee, which sometimes produced rather clumsy constructions (Vill damen ha något mer innan damen går? 'Does the lady want something else before the lady leaves?'). The pervasive and rapid change to $\mathrm{T}(d u)$ in almost all parts of public life is also explained by the Swedish socio-political climate of the 1960s with its democratic ideals and focus on egalitarianism. However, a much cited study by Mårtensson (1986) suggested that the $\mathrm{V}$ pronoun, $n i$, was reintroduced in Sweden in the 1980s as a polite pronoun used predominantly by young service staff to address older customers in particular. Mårtensson argued that her respondents were too young to have experienced the social stigma attached to $n i$; to them $n i$ was simply a polite distance pronoun, similar to vous in French or Sie in German, suitable for managing social roles in service situations. Subsequent studies on Swedish address, also based on reported use, have not found that $n i$ has been reintroduced, except that in service encounters $n i$ sometimes serves as 'a thin social veneer, which disappears as soon as the participant roles change ever so slightly' (Clyne, Norrby \& Warren p.112).

The development in Finland Swedish is similar, although the $d u$-reform was not as pervasive as in Sweden; in Finland $n i$ was preserved as a possible option in certain situations, particularly in interactions with older unfamiliar addressees and in service encounters (Clyne, Norrby \& Warren 2009). More recent observations of Finland Swedish address suggest that the development runs in two different directions: on the one hand $n i$ seems to hold and increase its role as a polite distance pronoun in service encounters in shops, 
cafés and restaurants, while, on the other hand, public authorities in Finland have introduced explicit $d u$ address in the past decade (Lassus 2010).

Despite the strong position of $\mathrm{T}$ as default address in both national varieties of Swedish, the socio-cultural developments in the mid and late $20^{\text {th }}$ century suggest that the address practices are complex, particularly in service encounters. Alongside $\mathrm{T}$ and $\mathrm{V}$, other options - such as no address and indirect constructions - also exist as resources for managing interpersonal relationships in both varieties. It should also be borne in mind that older speakers, particularly in Sweden, tend to view $n i(\mathrm{~V})$ negatively, as a condescending type of address, whereas younger speakers who lack experience of the address system prior to the shift to $d u$ following the ' $d u$ reform', are more likely to view it positively as a polite pronoun (Clyne, Norrby \& Warren 2009).

\section{Data}

The empirical basis of the chapter is a dataset of 318 audio and video recorded service interactions between customer and staff, equally distributed across Sweden Swedish and Finland Swedish. Recordings were made at a total of seven theatre box offices, event booking venues and the like, four in Sweden and three in Finland. The 318 customers were served by a total of 16 staff, 12 in Sweden and four in Finland. The age range of the customers was 16-87 in Sweden and 18-89 in Finland. Among staff, the age range was 1964 in Sweden and 25-58 in Finland. The lower number of staff in the recordings from Finland is explained by the fact that most interactions in public life in Finland take place in Finnish, leaving only few (and smaller) venues where the conversational language is Swedish. ${ }^{3}$ Table 1 summarizes the data. ${ }^{4}$

Table 1. Participants in the service encounter study

\begin{tabular}{lcccccc}
\hline & & Staff & \multicolumn{4}{c}{ Customers } \\
& Below 50 & Above 50 & Total & Below 50 & Above 50 & Total \\
\hline Sweden & 8 & 4 & 12 & 58 & 101 & 159 \\
Finland & 2 & 2 & 4 & 49 & 110 & 159 \\
Total & 10 & 6 & 16 & 107 & 211 & 318 \\
\hline
\end{tabular}

${ }^{3}$ The data were collected within the binational research programme Interaction and Variation in Pluricentric Languages supported by Riksbankens Jubileumsfond (Grant ID: M12:0137).

${ }^{4}$ We have divided the participants into two age groups: above and below 50 years. A more fine-grained division would result in some groups being too small, but more importantly, the division reflects the impact of the $d u$-reform in the late 1960s. Participants who were below 50 at the time of data collection were born in 1965 or later, and have not had any first-hand experience of the $d u$-reform, or the address conventions that led to the shift to near universal $d u(\mathrm{~T})$. Those above 50 , on the other hand, belong to generations that have been said to be ardent supporters of universal $\mathrm{T}$. 
Tables 2 and 3 provide an overview of the quantitative results presented and discussed in Norrby et al. (2015a). The purpose of the quantitative analysis was to explore what address patterns are used in the data and what the main similarities and differences are between Sweden-Swedish and Finland-Swedish service encounters. We based the analysis on whether a particular pattern, such as $\mathrm{T}$ address, $\mathrm{V}$ address and plural uses of the pronoun $n i$, occurs in the interactions in question. For example, the category 'T only' in Table 2 means that the customers use the T pronoun $d u$ at least once during the interactions, but do not use $\mathrm{V}$ or plural $n i$. The category ' $\mathrm{T}$ and plural $n i$, on the other hand, means that they use both $d u$ and plural $n i$ at least once. Interactions where the customers do not use $\mathrm{T}, \mathrm{V}$ or plural $n i$ are referred to as cases of 'no address'.

Table 2. Number of interactions with different types of address by customers in the data

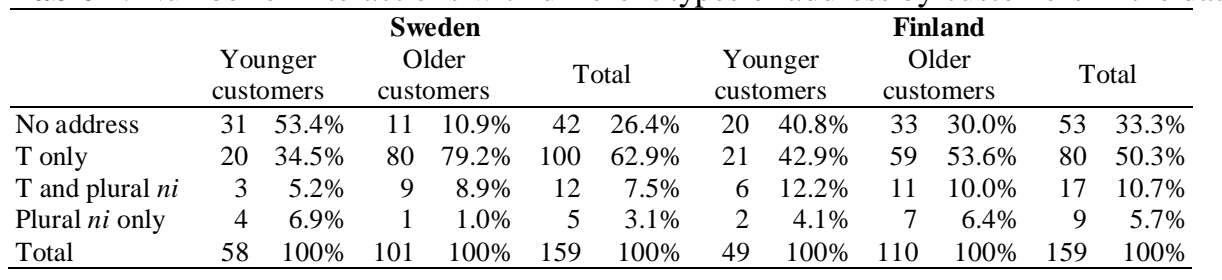

As Table 2 shows, $T$ address is the most common strategy among the customers in the data. Some unexpected differences, however, surfaced, when the customers were divided into age groups. This concerns Swedish customers in particular: younger customers have a much smaller proportion of $\mathrm{T}$ address than older customers ( $\mathrm{T}$ only in $34.5 \%$ vs. $79.2 \%$ of the interactions). The most prevalent pattern among younger customers in Sweden was clearly 'no address'. In the Finland-Swedish dataset the differences were much smaller between the age groups.

In the case of staff the results were quite different. On the one hand, there was much more variation in address strategies. As seen in Table 3, some staff also use $\mathrm{V}$ address, which the customers do not use at all. The use of the $\mathrm{V}$ pronoun $n i$ often co-occurs with the use of other address pronouns, which results in several additional combinations compared to the patterns found among customers. On the other hand, the group which stands out among staff are young Finland-Swedish staff members. 
Table 3. Number of interactions with different types of address by staff in the data

\begin{tabular}{|c|c|c|c|c|c|c|c|c|c|c|c|c|}
\hline & \multicolumn{6}{|c|}{ Sweden } & \multicolumn{6}{|c|}{ Finland } \\
\hline & \multicolumn{2}{|c|}{$\begin{array}{c}\text { Younger } \\
\text { staff }\end{array}$} & \multicolumn{2}{|c|}{$\begin{array}{c}\text { Older } \\
\text { staff }\end{array}$} & \multicolumn{2}{|l|}{ Total } & \multicolumn{2}{|c|}{$\begin{array}{c}\text { Younger } \\
\text { staff }\end{array}$} & \multicolumn{2}{|c|}{$\begin{array}{c}\text { Older } \\
\text { Staff }\end{array}$} & \multicolumn{2}{|c|}{ Total } \\
\hline No address & 20 & $19.6 \%$ & 12 & $21.1 \%$ & 32 & $20.1 \%$ & 37 & $40.7 \%$ & 12 & $17.6 \%$ & 49 & $30.8 \%$ \\
\hline T only & 68 & $66.7 \%$ & 33 & $57.9 \%$ & 101 & $63.5 \%$ & 21 & $23.1 \%$ & 31 & $45.6 \%$ & 52 & $32.7 \%$ \\
\hline $\mathrm{T}$ and plural $n i$ & 9 & $8.8 \%$ & 10 & $17.5 \%$ & 19 & $11.9 \%$ & 0 & $0 \%$ & 12 & $17.6 \%$ & 12 & $7.5 \%$ \\
\hline $\mathrm{T}$ and $\mathrm{V}$ & 1 & $1.0 \%$ & 0 & $0 \%$ & 1 & $0.6 \%$ & 5 & $5.5 \%$ & 1 & $1.5 \%$ & 6 & $3.8 \%$ \\
\hline V only & 0 & $0 \%$ & 0 & $0 \%$ & 0 & $0 \%$ & 14 & $15.4 \%$ & 1 & $1.5 \%$ & 15 & $9.4 \%$ \\
\hline $\mathrm{V}$ and plural $n$ & 0 & $0 \%$ & 0 & $0 \%$ & 0 & $0 \%$ & 5 & $5.5 \%$ & 2 & $2.9 \%$ & 7 & $4.4 \%$ \\
\hline Plural $n i$ only & 4 & $3.9 \%$ & 2 & $3.5 \%$ & 6 & $3.8 \%$ & 9 & $9.9 \%$ & 9 & $13.2 \%$ & 18 & $11.3 \%$ \\
\hline Total & 102 & $100 \%$ & 57 & $100 \%$ & 159 & $100 \%$ & 91 & $100 \%$ & 68 & $100 \%$ & 159 & $100 \%$ \\
\hline
\end{tabular}

As the quantitative survey of staff address reveals, T address is the most common category for all staff except for younger Finland Swedish staff where no address is the most frequent ( $40.7 \%$ of interactions). In addition, most cases of $\mathrm{V}$ address could be found in interactions with young FinlandSwedish staff. No great differences were found among younger and older Sweden-Swedish staff and the distribution of address patterns among older Finland-Swedish staff did not differ much from those of older SwedenSwedish staff (except for a few cases of $\mathrm{V}$ address and a slightly higher proportion of interactions with plural $n i$ ).

The quantitative analysis of the service encounter data thus revealed some interesting variation in how customers and staff position themselves through address in service encounters. The purpose of this article is to explore this variation in more detail from a qualitative perspective.

\section{Analysis}

In the following we investigate the impact of participant roles, nationality and age/generation in more detail through a qualitative analysis of 18 extracts. In addition, we explore a fourth dimension, situation, which was not analysed in Norrby et al. (2015a), but which clearly influences the choice of address.

To begin, we show two short service encounters in their entirety as an illustration of the two main patterns of address use in our data: address with $\mathrm{T}(d u)$ and with no direct address at all. $(\mathrm{C}=$ Customer, $\mathrm{S}=$ staff; address forms are highlighted in bold. For transcription conventions, see list at the end of the chapter.)

(1) Picking up pre-booked ticket, Sweden-Swedish; T address (GOT161; S: female, 19; C: male, 51)

1 C: jag har det här att hämta ut ((hands a note to staff))

2 S: japp tackar 'I have this to pick up'

3 (11.0) ((S reads booking reference and works on 


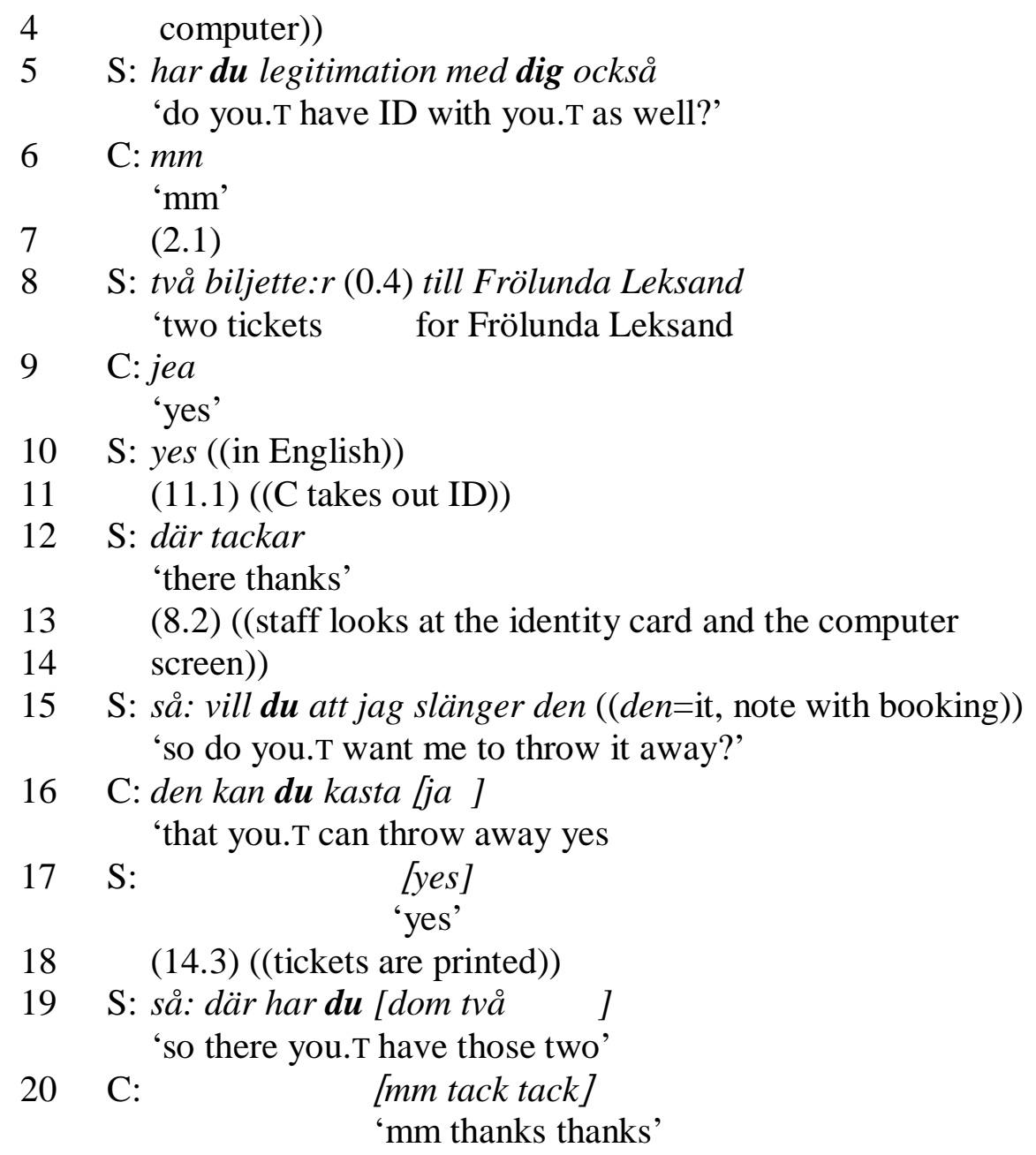

(2) Picking up pre-booked ticket, Sweden-Swedish; no direct address

(GOT035; S: male, 23; C: male 41)
1 C: [hej]
'hi'
2 S: [hej]
'hi'
3 C: den ((hands over a note)) och här e n:um:ret 'this and this number'
$4 \quad((\mathrm{C}$ hands over mobile phone $))$
5 S: tack 'thank you'
$6 \quad$ (8.0) ((S searches on computer $))$
7 S: varsågod ((hands back mobile phone) 'there you are'
8 C: tack 'thank you' 


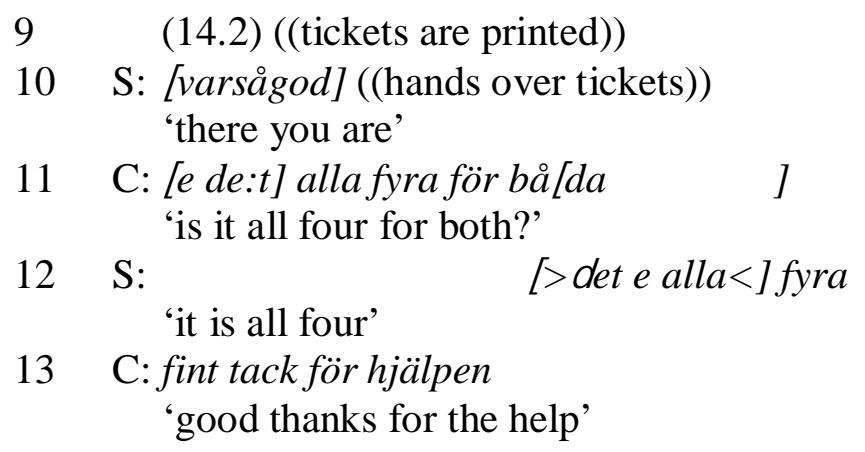

The interactions shown in extract (1) and (2) are in many ways similar. They take place at the same venue (a box office which sells tickets to sports events mainly), and involve the same type of transaction (collecting pre-booked tickets) where the customer initiates the interaction by handing over something (piece of paper, mobile phone). Yet, (1) displays several instances of $\mathrm{T}$ address whereas (2) has no instances of direct address. We will return to these extracts later in the analysis below, but let us first consider the variables identified as important for social positioning through address, starting with participant roles.

\subsection{Participant roles}

In all of the interactions a staff member serves a customer who in the majority of cases has come to buy tickets or to collect pre-booked tickets. In a few cases the customer requests more general information about an event, or wants to change a booking, and in a few instances the service encounter concerns matters other than tickets. As indicated in tables 2 and 3 there is a distinct difference in address patterns between customers and staff.

\section{Customer}

The most frequent overall pattern among customers is direct $\mathrm{T}$ address with the pronoun $d u$ as extract (3) from the opening of the interaction illustrates ( $\mathrm{T}$ forms are bolded). (See also (1) above.)

(3) Customer, Finland Swedish; T address, (AST023; S: 58, C: 54)

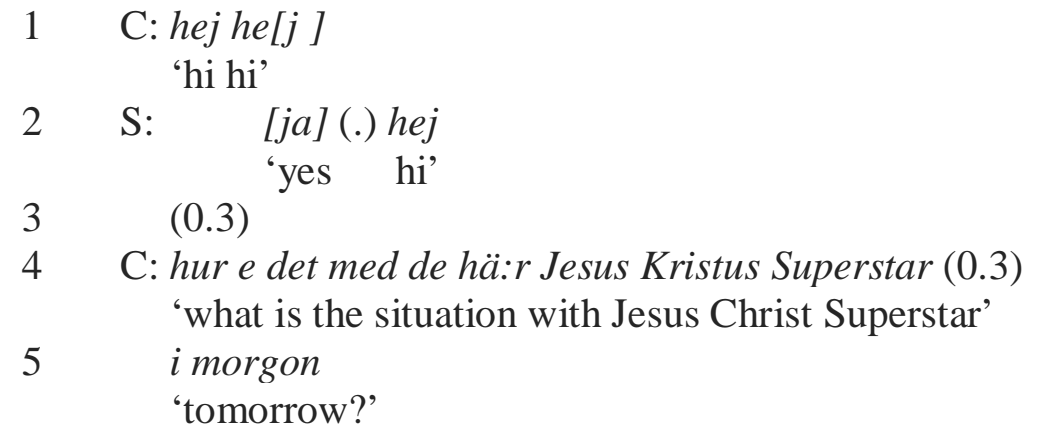


In (3) the customer presents the reason for the visit - inquiring about ticket availability - by addressing the staff member directly with the T pronoun $d u$ : har du någo biljetter kvar 'do you.T have any tickets left' (1. 7). By addressing the staff member directly, the customer foregrounds interpersonal relationships where the request for tickets is directly linked to the staff member's ability to provide them.

The quantitative results, however, also revealed that a recurrent pattern for customers is to not address the staff member at all (about 30\%), as illustrated in (4) and (5) below (see also extract (2) above.)

(4) Customer, Sweden Swedish; no direct address (DRA002; S: male, 27; C: female, 33)

1 S: hej 'hi'

2 C: hej (.) $i$ kväll, (.) Fanny och och (.) [oAlexander] tacko 'hi (.) tonight, (.) Fanny and and (.) Alexander please'

$3 \mathrm{~S}$ S:

$4 \quad$ hur många 'how many?'

5 C: eh: två stycken 'eh: two tickets'

(5) Customer, Finland Swedish; no direct address (HEL066; S: female, 25; C: female, 70)
$1 \quad$ C: $m t h e j$
2 S: hej
'hi'
$3 \quad(0.8)$
4 C: på namnet LAST NAME FIRST NAME två biljetter
'in the name
$5 \quad$ till Kappan nu i kväll

[mm $]$

'mm'

'for The coat now this evening'

In both these extracts the customer delivers the information necessary to complete the transaction in a succinct way, including the name of the play, the date and number of tickets, but without addressing the staff member directly (for further discussion, see 4.4 below). 
In some of the service encounters, the customer displays social positions through address immediately after greetings and before formulating a request through the use of vocative T, as illustrated in (6) where the customer is enquiring about tickets for a soccer game. This use is typical of the Sweden Swedish data.

(6) Customer, Sweden Swedish; T address (GOT014; S: male, 29; C: female, 68)

1 C: $h e j$

'hi'

2 S: hej

'hi'

3 C: du jag skulle ha två biljetter till är det IFK gävle 'you.T.VOC I would like two tickets to is it IFK Gävle'

4 som spelar tjugosjätte september (1.0) IFK nått who are playing on the twenty-sixth of September IFK something'

A similar positioning can result from the use of a discourse particle containing T address, such as hördu 'listen+you.T'. Extract (7) illustrates this use, which is typical of the Finland-Swedish dataset.

(7) Customer, Finland Swedish; T address (ABO143; S: male, 29; C: female, 75)

1 S: [hej]

'hi'

2 C: [hej]san hejsan (0.4) hör du (.) den där (.)

'hi hi listen[+you.T] this' skärgårdskalendern 'archipelago calendar'

$4 \quad$ S: $j a ̊$ 'yes'

5 C: vad kostar den 'how much is it?'

6 S: den e tretti euro 'it's thirty euros'

$7 \quad(0.2)$

8 C: tret-vi ska se-näe du kan inte ta bankkort va 'thirt- let's see no you.T don't take debit cards do you?'

9 S: nä: tyv[ärr] 'no sorry'

10 C: $\quad$ [näe] näe men hör du jag kommer 'no no but listen[+you.T] I'll come'

11 se[nare jag har bara ] 
'later I only have'

The use of vocative $d u$, as in (6), and the particle $h \ddot{r} r d u$, as in (7), both function as a means for attracting the attention of the interactional partner, the member of staff, before presenting the reason for the visit. In other words, the customers position themselves from the outset as speaking directly to the other person rather than to the institution which provides a service.

It is noteworthy that there are no cases of customers addressing the staff with $\mathrm{V}(n i)$ in our data. In (8) below the customer uses the pronoun $n i$ initially (1. 4), but as the ensuing interaction makes manifest, this is not an instance of $\mathrm{V}$ address (i.e. $n i$ to address one person more formally).

(8) Customer, Sweden Swedish; plural $n i$ and T pronoun $d u$ (GOT028; S: male, 23, C: female, 57)

$1 \quad \mathrm{C}:$ hej [jag] skulle vilja beställ- eller köpa biljetter till KIDS 'hi I would like to rese- or buy tickets for KIDS'

2 S: [hej]

'hi'

$3 \quad \mathrm{~S}: j a a_{i s E ;}^{i s]}$

'yes'

4 C: har ni nånting den nu ska vi se 'do you.PL have anything on the now let's see'

$5 \quad$ var jag hade sett det (.) istep? 'where I have seen it'

$6 \quad$ lördagen den sextonde $i$ elfte

'Saturday the sixteenth of November?'

$7 \quad$ S: jag kollar

'let me check'

((4 lines omitted when S. checks availability))

8 S: nej jag har inga där tyvärr alls

'no, I have none at all, unfortunately'

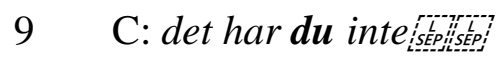

'oh, you.T don't'

When the customer asks about tickets (1. 4), this is a case of addressing the institution as a collective (plural ni) har ni nånting... 'do you.PL have anything...' rather than addressing the staff as an individual (cf. extract (6) above). This interpretation is supported by the unfolding interaction where the customer addresses the staff later on (1.9) directly with $\mathrm{T}(d u)$ when receiving the negative news about ticket availability (see also extract (3) for 
a further example). Use of plural $n i$ to address the institution is a recurrent pattern in the data. In terms of social positioning, plural ni puts the emphasis on the institution providing a service rather than the interlocutor as a person.

Staff

With staff, the address behaviour is much more complex: besides the ubiquitous use of $\mathrm{T}$ address, there are service encounters where the staff member does not address the customer directly at all (see extract (2) for an example), as well as cases where the staff uses V address. In fact, all the following combinations exist in the data: $\mathrm{T}$ only, $\mathrm{T}$ and plural $n i$, plural $n i$ only, $\mathrm{V}$ only, $\mathrm{V}$ and plural $n i$ and no address at all (see Table 3).

In (9), the direct continuation of (5), the staff member addresses the customer directly with $\mathrm{T}$.

(9) Staff, Sweden Swedish; T address (DRA002; S: male, 27; C: female, 33)

$1 \quad \mathrm{~S}: m_{i}$ (.) vilken sektion vill du \#sitta i\#

'mm which section do you.T want to sit in?'

2 C: eh: jag tro- (.) jag va inne å titta på: (0.4)

'eh I think- I checked'

3 eh Dramatens hemsida

'eh the Dramaten website'

The second most common category also among staff is no direct address (ca $25 \%$ ) as illustrated in extract (2) above and extract (13) below. There are also a few cases with $\mathrm{V}$ address, but except for one single case (see Norrby et al. 2015a) they are restricted to the Finland-Swedish data. Extract (10) shows a case from one of these encounters.

(10) Staff, Finland Swedish; V address (HEL055; S: female, 25; C: female, 46)

$1 \quad$ ((C pays by credit card))

2 S: $m t$ (.) eh om ni tar ut å sätter [in på ny]tt så borde det 'if you.V remove [the card] and insert [it] again it should [work]'

3

$\mathrm{C}$ :

4

$$
\begin{aligned}
& \mathrm{S}: \text { vi ska se (0.3) näe }(0.5) \\
& \text { 'let's see no' }
\end{aligned}
$$

In (10) the customer is trying to pay with her credit card but the credit card machine does not work properly. In line 2 the staff asks the customer to remove her card. When doing so she uses V address: om ni tar ut å sätter in på nytt så borde det 'if you. $\mathrm{V}$ remove [the card] and insert [it] again it should 
[work]'. Later on, when she has fixed the machine, she uses a construction without address when she asks the customer to sign the receipt: om jag får underskrift där tack 'if I can have a signature there, please'.

While the pronoun $n i$ is only used by the Finland-Swedish staff to convey $\mathrm{V}$ address, both Finland-Swedish and Sweden-Swedish staff use the pronoun $n i$ with plural meaning to collectively refer to several customers. This use of $n i$, illustrated in (11) below, has a similar function as the customers' use of collective $n i$ analysed in (8).

(11) Staff, Finland Swedish; plural ni (AST021; S: female, 58; C: male, 77)

S: å hur många personer e ni

'and how many persons are you.PL'

2 C: fyra

'four'

$3 \quad(0.7)$

4 S: å och har du varit å tittat på vår hemsida vad ni vill ha 'and and have you.T looked at our website, what you.PL want?'

In (11) the staff member first asks the customer how many people will attend the play that he is buying tickets to. When she uses the pronoun $n i$ 'you.PL' in line 1 she refers to the customers collectively. Given the referential meaning this is the only possible interpretation. This is also the case at the end of line 4 where she is inquiring about the customer's reservation concerning refreshments during the interval. She starts her inquiry by using $\mathrm{T}$ address to refer to the customer alone, å och har du varit å tittat på vår hemsida 'and have you.T looked at our website', before she proceeds to talk about the whole group he is buying the tickets for, vad ni vill ha "what you.PL want'.

To summarize, staff make use of a greater variety of address patterns than customers when they position themselves in the service encounters investigated. Partly this is related to the fact that they act in a professional role and perform more varied actions in the service encounter. In comparison, the customers are not accountable for providing a service and hence may not have to carry out as much interactional work. Some of the variation, however, has to do with the fact that the address system in Finland-Swedish is not stable, which opens up for several different strategies depending on how the staff members choose to manage the relation to the customers (see section 4.4). 


\subsection{Nationality}

The quantitative study (Norrby et al. 2015a) demonstrated some differences in address use between Finland-Swedish and Sweden-Swedish participants. This is true in particular of staff. The most striking feature is the variation in address forms among the Finland-Swedish staff, both in terms of types of expressions used and between individual staff members (see Table 3). In the Sweden-Swedish data, staff clearly favour T. Overall, the number of interactions where staff address their customers directly with $\mathrm{T}$ only is higher in Sweden (63.5\% compared to $32.7 \%$ in Finland, Table 3). However, one (older) staff member in Finland positions herself in the same way as her Sweden-Swedish colleagues and addresses her customers with $\mathrm{T}$, and never with V. Extract (12) illustrates this.

(12) Staff, Finland Swedish; T address (HEL002; S: female, 53; C: female, old, unspecified age)

$1 \quad$ S: var vill du sitta där finns platser nu liksom 'where do you. T want to sit there are seats like there now?' $(0.5)$

C: hördu: ja nå an-eh (.) vad e den där trettonde 'listen[+you.T] yes well what's that thirteenth?'

$4 \quad(0.4)$

5 C: nej vad e den där (0.4) där där där (.) man har 'no what's that there there there do you have'

6 plats för benen 'space for your feet?'

$7 \quad(0.4)$

8 S: sextonde 'the sexteenth?'

9 C: $o k e j$ 'okay'

$10 \quad(0.3)$

$11 \mathrm{~S}$ : där e $m$ - (.) ledigt runtomkring så du flyttar 'there are seats free around it so you.T just move'

12 var du tycker sen 'where you.T want then'

13 C: så jag får v:räka mig 'so I can spread out'

14 S: du får göra det 'you.T can do that'

$15 \quad(0.4)$

16 C: kiva 'nice'

$17 \quad(0.8)$ 
In (12) the 52-year old staff member uses $\mathrm{T}$ address several times to address the customer, who is clearly older than herself, starting with var vill du sitta 'where do you want to sit' (line 1). In this particular interaction the customer also uses $\mathrm{T}$ several times to address the staff, for example in line 3 , which is a response to the staff's preceding turn with $\mathrm{T}$ address. The staff member, however, uses $\mathrm{T}$ address consistently throughout the encounters that she participates in, in some cases numerous times even though the customer does not address her directly at all.

The address behaviour of the other Finland-Swedish staff members - and hence their social positioning - varies depending on factors relating to the customer (such as age), but also according to how they present themselves in their professional role. The individual staff members seem to favour slightly different types of address strategies and apply them more or less indiscriminately in all interactions. While the older staff member in extract (12) favours T address with $d u$ in a similar way as Sweden-Swedish staff, the younger staff member, who works at the same venue, favours $\mathrm{V}$ address (V address in 20 of 37 interactions, see extract 10). The other older FinlandSwedish staff member uses $d u$ in half of 33 interactions, but uses V address in only four cases. Instead, she uses plural $n i$ in 13 interactions; one of the cases was illustrated in (11) above. Finally, the other Finland-Swedish younger staff member has the highest share of no direct address in the Finland-Swedish data: in slightly more than half of the 54 interactions she does not use any address pronoun at all. One of these cases is shown in (13) below.

(13) Staff, Finland Swedish; no direct address (ABO001; S: female, 29; $\mathrm{C}$ : male, 80)

1 S: sen önska dom från röda korset jag skulle ta upp 'then they asked me from the Red Cross to write down' 2 ännu .hh namn och (.) kontaktuppgifter telefon[nummer] 'also the name and contact information telephone number' C: [ja hap ]
4 C: LAST NAME
$5 \quad(0.2)$
6 S: $n j a+a$ : 'well'
$7 \quad(0.8)$
8 S: LAST NAME
$9 \quad(0.7)$
10 C: FIRST NAME och FIRST NAME
11 (4.3)
12 S: å en telefonnummer räc[ker riktigt bra] 


\author{
'a phone number is enough' \\ ((ten lines omitted: customer gives his phone number)) \\ $13 \quad(0.6)$ \\ 14 S: yes och det blir så mycket som hundra euro \\ 'yes and that's hundred euros altogether'
}

In (13) the 80-year old customer is signing up himself and his wife for a party organized by the Red Cross. The member of staff needs to pass on his name and telephone number to the Red Cross. Instead of asking the customer directly for this information she uses constructions without direct address: sen önska dom från röda korset jag skulle ta upp ännu .hh namn och (.) kontaktuppgifter telefonnummer 'then they asked me from the Red Cross to write down the name and contact information telephone number' (1. 1-2). As seen in line 3-10 the customer responds to this as a request and provides the staff with his name. He does, however, not give the staff his phone number, and in line 12 she reminds him by saying å en telefonnummer räcker riktigt bra 'and a telephone number is enough'. Again, the customer treats this as a request and provides his telephone number. After receiving the information needed, the staff proceeds to talk about the payment. She starts by using the informal discourse particle yes (said in English) before stating the total price.

In contrast to the cases without direct address shown in extract (2) above, the member of staff in (13) seems to consciously avoid addressing the customer. Avoiding direct address also more generally seems to be a strategy for her to position herself in the interaction with customers. Of all the staff members in the data, she has the lowest frequency of direct address. She is also the only staff member who uses direct address less than the customers she is talking to. At the time of recording, she commented on this strategy by telling the research assistants that she had started using constructions without direct address when working for another service provider since she found it difficult to conform to the house rule of $\mathrm{V}$ address to all customers, even those her own age.

In summary, in terms of national variation staff position themselves somewhat differently in Sweden and Finland. In Sweden, they typically address customers habitually with $\mathrm{T}(d u)$, whereas staff in Finland display much more variation in how they address customers. Each one of the Finland-Swedish staff seems to favour a certain address strategy and tend to apply it more or less consistently in their interactions with customers. In this sense address can be seen as a conscious choice made by individuals in their professional role as staff, but in addition, the analysis suggests that the address strategies correlate with age, with younger staff favouring $\mathrm{V}$ address or no direct address. In the next section we explore age/generation in more detail. 


\subsection{Age/generation}

The quantitative results illustrate that, overall, address behaviour is more clearly linked to age than to any other factor. Customers above 50 years in both Sweden and Finland undoubtedly favour use of T address $(d u)$ whereas customers below the age of 50 display much greater use of no address. In particular, this is the case among younger Swedes: in more than 50 per cent of the service encounters where the customer is below 50 they do not address the staff member directly at all. Extract (14) shows how a 21-year-old customer is collecting pre-booked tickets without addressing the staff directly at all (See also extracts (2), (4) and (5) above for further examples of this practice.)

(14) Customer, Sweden Swedish; no direct address (GOT008; S: male, 29 C: male, 21)

1 C: tjena 'howdy'

2 S: tjena 'howdy'

3 C: e::h jag tänkte lösa ut två: Frölundabiljetter 'eh I was going to collect two Frölunda tickets'

$4 \quad$ tills $i$ morn ((holds out a piece of paper)) 'for tomorrow'

5 S: jajemän du hade bokningsnummer där också va

$6 \mathrm{C}: \mathrm{mm}$ 'for sure you had a booking number there too right' 'mm'

7 S: nåns- (0.7) ${ }^{\circ}$ där hittar vi ${ }^{\circ}$ ((looks at paper with booking)) 'somewhe- there we have'

8 (13.2) ((staff working at the computer))

9 S: sådär 'there'

$10 \quad$ (3.5) (( tickets are printed $))$

11 S: ${ }^{\circ}$ sådär då (0.4) $o j^{\circ}$ 'so there then woops'

12 (13.8)

13 S: så där då 'so there then'

14 C: sådär tack så mycket 'so there thanks so much'

15 S: varsågod 'here you are'

16 C: ha det gött 'take it easy' 


\section{S: detsamma \\ 'you too'}

The customer presents the reason for the visit directly after the greeting sequence (1. 3-4): jag tänkte hämta ut två biljetter till Frölundamatchen tills i morn 'I was going to pick up two Frölunda tickets for tomorrow' in a turn which contains all necessary information for the staff to proceed with the request. The customer specifies the number of tickets, the game and date and hands over a document with a booking reference (evident from the member of staff's turn in 1. 5). Immediately after locating the booking reference the member of staff starts issuing the tickets while the customer is waiting in silence. The whole interaction is brief (46 seconds), to the point, and there is no need for the customer to address the staff directly.

While the practice of not addressing the staff at all is a common pattern among younger customers in Sweden, it is rare among older Swedish customers who address the staff directly with $d u$ in ca $90 \%$ of interactions. In (15) we see how the customer addresses the member of staff with $d u$ several times:

(15) Sweden Swedish; T address (DRA004; S: male, 27; C: male, 69)

$$
\begin{aligned}
& 1 \text { S: hej } \\
& \text { 'hi' } \\
& 2 \text { C: } h e j \boldsymbol{d u} \\
& \text { 'hi you.T' } \\
& 3 \quad(0.3)
\end{aligned}
$$

$4 \quad$ C: du ja:geh (0.9) mt bokat eh: 'you.VOC.T I eh (0.9) mt booked eh'

5 ett antal biljetter på nätet va 'a number of tickets on the internet right'

$6 \quad \mathrm{~S}: \mathrm{mm}$ ' $\mathrm{mm}$ '

7 C: till Amadeus eh: (1.9) eh: åtta stycken 'for Amadeus eh eh eight tickets'

8 å här e bokningsbekräftelsen (0.2) 'and here is the booking confirmation'

9 hämta dom här ((hands over paper with booking)) 'pick up these'

10 S: [mm] javisst 'mm of course'

((15 lines omitted: $S$ processes the order, customer pays and asks when the doors open))

11 (5.9)

12 C: tack ska du ha

'thank you. $\mathrm{T}$ ' 


\section{S: tack \\ 'thank you'}

As in extract (14) the customer has come to collect pre-booked tickets and presents the central information immediately after the greeting sequence: the name of the play, number of tickets and a booking confirmation. But contrary to (14), the customer addresses the member of staff directly, both when greeting: hej $d u$ and when presenting his reason for the visit: $\boldsymbol{d u}$ jag $e h$ (0.9) $\mathrm{mt}$ bokat eh här ett antal biljetter... 'you.VOC.T. I have booked here a number of tickets...' (see also extract (6) for similar vocative use of the T pronoun in the Sweden-Swedish dataset). Obviously, there is no need for addressing the staff directly in this environment as illustrated by (14) above. However, by using two instances of $d u$ in the first possible positions immediately after the greeting and initially when presenting his errand - the customer emphasises social (interpersonal) relationships between himself and his interlocutor.

Also younger customers in Finland tend to favour no address; in $40.8 \%$ of all encounters customers do not address the staff directly. However, the difference between younger and older customers is much less pronounced in the Finland-Swedish dataset (see table 2).

Among staff, age does not emerge as a factor in address choice in Sweden. Irrespective of age, staff use T address (including plural $n i$ ) in around $80 \%$ of the interactions, and in the remaining cases there is no direct address. In the Finland-Swedish data, however, there are some compelling differences related to age. Firstly, V address is primarily used by the younger staff members, and, secondly, its use in most cases seems to be related to the age of the customer. The young staff member who uses $\mathrm{V}$ address the most, uses it with most of the customers who are approximately ten years older than herself or more (see (10) above). As (16) illustrates, she sometimes switches to $\mathrm{T}$ address during the interactions.

(16) Staff, Finland Swedish; V and T address (HEL055; S: female, 25;

C: female, 47)

1 S: [hej]

'hi'

$2 \mathrm{C}:[h e] j$

' $h i$ '

$3 \quad(1.3)$

$4 \quad$ (customer is eating an ice-cream))

5 C: FIRST NAME (0.9) LAST NAME (0.5) jag har en biljett

6 på tredje rad[en]

'I have a ticket'

$7 \mathrm{~S}$

'on the third row in the stalls'
S:
[ju ]st det det var <ni som ringde> 


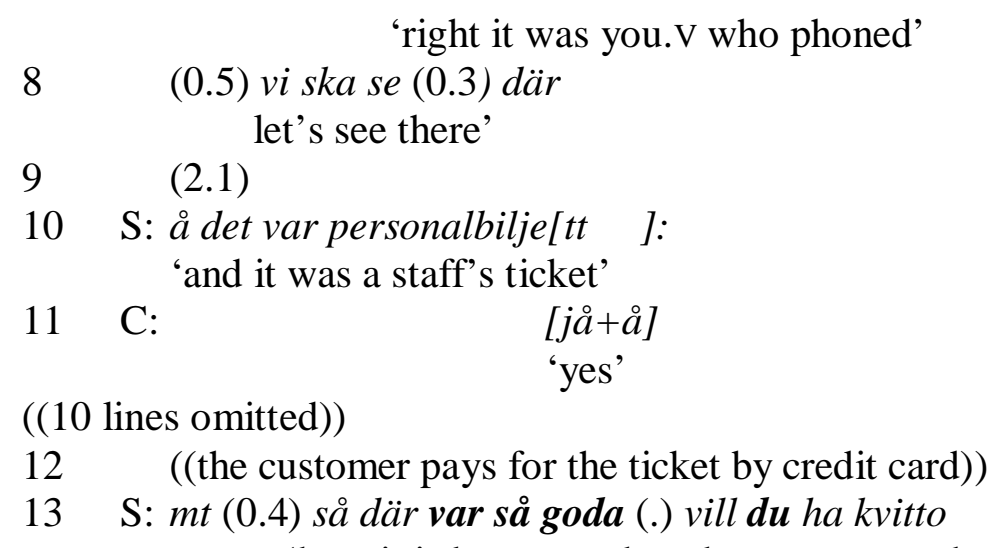

'here it is be so good.PL do you.T want the receipt?'

In (16) the 47-year old customer is alone and is picking up one ticket for herself. After she has told the staff about her ticket reservation (1. 5-6), the member of staff responds by addressing the customer with $\mathrm{V}$ : just det det var ni som ringde 'right it was you. $\mathrm{V}$ who phoned' (1. 7). In line 13 she uses the plural form var så goda 'be so good', which typically accompanies $\mathrm{V}$ address used by younger persons. However, in the same line, just following a micro pause, she uses T address when she asks the customer if she wants a receipt: $m t$ (0.4) så där var så goda (.) vill du ha kvitto 'mt here it is be so good.PL do you.T want the receipt'. In this particular case, nothing happens that would motivate a change of address pronouns, which shows how thin a veneer V address is also in Finland (cf. Clyne, Norrby \& Warren 2009: 112). Those who use $\mathrm{V}$ address in service encounters can suddenly, without any interactional problems, switch to $\mathrm{T}$ address (and sometimes back to $\mathrm{V}$ again). Using both $\mathrm{T}$ and $\mathrm{V}$ address in the same interaction is in fact quite common in Finland (Lappalainen 2006, 2015, on Finnish).

\subsection{Situational factors}

In addition to the factors discussed so far, situational factors are important for how social positions are expressed through address. Such factors include the type of venue (kind of services provided) and, relatedly, type of transaction (mainly requesting tickets without a pre-booking or collection of pre-booked tickets) and whether it is a highly routinised interaction or not, i.e. a straightforward request for tickets which the staff can provide with minimum effort, or something complicated or problematic which requires more negotiation, e.g. about dates or seat selection, or changes to a booking (see Lindström \& Wide, forthc.). In addition, potentially sensitive topics, such as the price or payment problems, can also appear in the local interactional context and influence how the interlocutors position themselves vis-á-vis one another. 
When the venue provides just a few services, i.e. tickets to a limited set of events, and where customers typically request this contextually predictable type of service, such as a ticket to tonight's ice-hockey game or theatre performance, there seems to be a preference for brief interactions focussing on the business at hand. This is illustrated in extract (17) below (see also (4) and (5) above):

(17) Customer, Sweden Swedish; request without direct address (GOT056; S: male, 23; C: male, 41)
$1 \quad$ C: [(hallå)] 'hello'
2 S: [hej ] 'hi'
3 (.)
4 C: Frölundamatchen 'the Frölunda game'
5 S: ja hur många ska du ha 'yes how many do you.T want?'
6 C: tre
'three'

After the greeting sequence the customer initiates his request simply with one word Frölundamatchen 'the Frölunda game'. There are numerous examples of this situationally dependent practice in our data where customers focus on the matter at hand and deliver their request without addressing the staff. At venues which sell tickets to a limited range of events there seems to be preference for interactions where the transaction is completed without delay; in particular, this is the case at the sports arena in (17), which is usually very busy with many customers waiting in line to carry out a situationally predictable transaction.

In service encounters which involve collecting pre-booked tickets, it is often the case that the customer initiates the interaction by giving a booking reference, sometimes verbally, but very often simply by handing over a piece of paper or a mobile phone with the booking details (see extracts (1), (2), (14) and (15) from the Sweden-Swedish dataset), or by giving the name in which the booking was made (see (5) and (10) from the Finland-Swedish dataset). This reflects different institutional practices for keeping track of pre-ordered tickets and customers position themselves as knowing customers by conforming to these practices.

With a pre-booking the successful outcome is predictable and, accordingly, customers tend to formulate their requests directly and to the point as we have seen in several extracts. In cases where the customer wants to buy tickets without a pre-booking, the request formulations are, however, less homogenous. On the one hand, there are numerous cases where the 
customer focuses on the target object without addressing the staff when making their request for tickets, as in extract (4): ikväll Fanny och Alexander två stycken 'tonight Fanny and Alexander two tickets'. The continuation of this interaction shows, however, that the customer has already checked the theatre's website and knows that there are tickets available (see extract (9)). Such pre-knowledge about ticket availability seems to promote directly formulated requests, similar to cases where the customer has pre-booked tickets.

This contrasts with cases where the customer does not display any such pre-knowledge and where the outcome is, from the customer's perspective, uncertain. In extract (8) the customer asks about tickets in a guarded way: hej jag skulle vilja beställ- eller köpa biljetter till KIDS... har ni nånting nu den nu ska vi se 'hi I was going to res- or buy tickets for KIDS...do you.PL have anything now the now let's see'. It is interesting to note that the customer is enquiring about tickets to a certain show, which is playing for a limited time only. This is very different from the sports events, such as the ice-hockey games which are played regularly, at least twice a week, throughout the season.

In other words, customers can position themselves as knowing parties who have the 'right' to demand a certain service from the company (in the case of pre-bookings), or display an expectation that their request will be granted (as when they have checked availability beforehand). In both situations, it is common not to use direct address. However, there are exceptions where the customer uses direct address in these situations (see (15) in particular, but also (6) and (7)). It seems that $d u$ in such cases serves the purpose of regulating interpersonal relationships where the customer turns to the staff member as an individual, there to help them.

Furthermore, in situations with some complication, or potential problem, this seems to generate more direct address; the complication generates more talk, and hence opportunities for addressing. Extracts (1) and (2) both begin with the customer providing a note with a booking reference accompanied by a verbal action. While the staff processes the order without much talk in (2), the next action in (1) is that the staff requests identification: har $d u$ legitimation med dig också 'do you.T have ID with you.T as well', addressing the customer directly twice. Later, when asking the customer whether to throw away the booking reference, the staff addresses the customer again: vill du att jag slänger den 'do you.T want me to throw it away'. Interestingly, the customer mirrors the staff in his response by also using direct address: den kan du kasta ja 'that you.T can throw out yes'. Finally, when handing the tickets to the customer the staff once again acknowledges the customer through direct address: där har du dom två 'there you.T have those two'. 
As demonstrated by extract (18) alternating between $\mathrm{T}$ and $\mathrm{V}$ forms in the Finland-Swedish service encounters can be attributed to a type of situational change which takes place locally, as the interaction unfolds:

(18) Staff, Finland Swedish; T and V address (ABO075; S: female, 29 member; $\mathrm{C}$ : male customer 89)

$1 \quad$ S: jag kan hjälpa fast om du tar å viker 'I can help but if you.T fold'

$\mathrm{C}$ : ja det $f$ - kanske bäst att du gör det 'well, maybe it is better if you.T do it' $3 \quad(0.8)$

4 S: å sådär (.) å ifall ni ville bidra med 'okay and if you.V wanted to contribute with'

$5 \quad$ nån summa så då ska man sätta det hit också 'an amount one can put it here as well'

6 C: ska ja- ska jag sätta slanten också dit 'shall I- shall I put the money there too'

In (18) the customer is voting for a candidate for the annual Lucia procession, a tradition in Sweden and Finland on December $13^{\text {th }}$. In Finland, the procession is often organized by charity organisations, which is also the case here. The 89-year-old customer is casting his ballot and the member of staff offers to help, addressing him with T: jag kan hjälpa fast om du tar $\stackrel{a}{~}$ viker 'I can help but if you.T fold' (1. 1). Directly after that, when she asks the customer whether he wants to contribute with an amount of money to the charity, she switches to $\mathrm{V}$ address followed by an impersonal construction with the pronoun man ('one'): å ifall ni ville bidra med nån summa så då ska man sätta det hit också 'and if you.V wanted to contribute with an amount one can put it here as well'(1. 4-5). The reason for the switch is most likely the sensitive nature of the topic. By not using $\mathrm{T}$ address, the staff positions herself differently to the customer and makes the question about a contribution less forceful.

\section{Discussion}

The results demonstrate some variation in social positioning through address which can be attributed to external factors, such as the participant roles (customer or staff), national variety (Finland-Swedish or Sweden-Swedish) and age (younger or older speaker and addressee) as well as situational factors that have to do with the type of venue, the type of transaction and micro-situational aspects which occur during the course of the interaction (complications, problems or topics treated as sensitive). Overall, both customers and staff use direct $\mathrm{T}$ address in the majority of interactions, which lends support to earlier research which - based on reported use - have 
proposed that $\mathrm{T}$ address is the default, or indeed neutral, form of address in contemporary Swedish (Clyne, Norrby \& Warren 2009).

Age is a factor which cuts across the national borders: younger customers, both in Sweden and Finland, behave similarly and differently from older customers, who display similar address patterns. In turn, this points to a similar development in society in the two countries where older participants position themselves in a similar way and have a much higher incidence of direct address, largely $\mathrm{T}$ address, whereas younger customers in both countries refrain from direct address to a much greater degree. Thus, it is possible that we are witnessing a shift in pragmatic orientation in the type of service encounters investigated here, where younger customers tend to focus more on the business at hand in order to achieve an outcome (e.g. purchase of tickets) without delay, whereas older customers are more tuned into establishing and upholding interpersonal relationships through the use of direct $(\mathrm{T})$ address. However, this is not to say that the age differences we register are solely explained by a change over time; absolute age most likely also plays a part here. In general, it can be expected that, with increased age, we have more experience and that this could be mirrored in address practices.

There is also some variation which can be linked to nationality. In Sweden, both young and older staff position themselves vis-à-vis their customer in the same way; staff use T address in the vast majority of interactions (close to $80 \%$ of service encounters include staff $\mathrm{T}$ irrespective of their age). Much debate, particularly in Sweden, has focused on the reintroduction of $\mathrm{V}$ address in service situations (see background section for a summary and references). However, with only one instance of $\mathrm{V}$ address in the Sweden Swedish data (younger staff to a customer about 15 years older) it is safe to conclude that $\mathrm{V}$ is not being introduced in service encounters of the type investigated here. In other words, there is no empirical support in our data for the diffusion of a new 'service $n i$ ' in Sweden for expressing polite distance, similar to $\mathrm{V}$ in French or German.

Traditionally, $\mathrm{V}$ address has not had equally negative connotations in Finland as in Sweden, and this is also borne out in the data: Finland-Swedish staff, and in particular younger staff, make some limited use of $\mathrm{V}$ (as a polite form of address). However, while the typical recipient of $\mathrm{V}$ would be somebody much older than the speaker, old age does not necessarily result in $\mathrm{V}$ address. Extract (18) illustrates the fluctuation between $\mathrm{T}$ and $\mathrm{V}$ to an elderly customer and highlights that there are other conditions than actual age or perceived age differences that might occasion a shift to $\mathrm{V}$. The fact that there is some evidence of both $\mathrm{T}$ and $\mathrm{V}$ address in the same interaction suggests that $\mathrm{V}$ is a thin social veneer that disappears as soon as there is a change in the social roles (away from the most routine-like service interaction). 
With T largely as the default address, use of T per se does not signal any particular closeness between interlocutors, but repeated use of $\mathrm{T}$ in an interaction can serve the purpose of accentuating social interrelationships and rapport over a factual focus on the transaction. Here it is particularly interesting to juxtapose service encounters with no direct address at all with those where there is a high frequency of direct $(\mathrm{T})$ address. For example vocative $\mathrm{T}$ and use of the particle hördu 'listen+you.T' are resources that customers sometimes seem to use in order to establish rapport from the outset.

\section{Concluding remarks}

In this chapter we have focused on social positioning through address practices. From an interactional linguistic perspective, we conclude that it is important to explore address terms (or lack of address terms) in their sequential context in order to understand their functions for social positioning of self and other. From the point of variational pragmatics, our results help shed light on the interplay between macro social factors, external to the particular interactions, as well as situational factors associated with the particular activity (service encounters at box offices) and the actions that evolve during the progression of the interaction (for example attending to problems that occur at a given moment).

Our study contributes to research on pluricentric languages, in particular Swedish as a pluricentric language. Previous research into the two national varieties, Sweden Swedish and Finland Swedish, has primarily focused on structural aspects of language, such as phonological, lexical, morphological and syntactic differences between the two national varieties (see e.g. Reuter 1992, Wide \& Lyngfelt 2009). Much less scholarship has been devoted to pragmatic and interactional variation, but most studies to date have suggested that Finland-Swedish pragmatic and interactional patterns are characterised by a higher level of social distance and formality than Sweden Swedish (Clyne, Norrby \& Warren, 2009:152, Norrby et al. 2015a, b). Our findings illustrate that this is a simplification; for example, younger customers behave similarly across the national borders, and differently from older ones, demonstrating that participant roles and the situational context may override national differences.

Interpreted through the lens of indexicality (Silverstein 2003) it could be argued that $\mathrm{T}$ in contemporary Swedish - and particularly in Sweden Swedish - simply indexes neutrality. However, repeated use of $\mathrm{T}$ seems to be a resource for lowering social distance and accentuating commonalities between the interlocutors (cf. Clark 1996 on common ground). As expected, $\mathrm{V}$ address is very limited in our data, and predominantly found among younger Finland-Swedish staff. They seem to use V to signal polite distance, predominantly in interactions with more senior customers. Accordingly, V indexes old age, and, more generally, otherness (cf. Clyne, 
Norrby \& Warren 2009:156). No direct address, however, a common pattern in our data, puts the emphasis on the transactional business rather than interpersonal relationships.

The differences between the two datasets, which can primarily be found among staff, point in the same direction as the results in Norrby et al. $(2015 b)$, where address practices in Sweden-Swedish and Finland-Swedish medical consultations were compared. While T address is the most common practice also in the Finland-Swedish service encounters that we have analysed, $\mathrm{V}$ address remains as an option which can be used in order to show respect to the customer by keeping a certain distance. This stronger tendency to keep their distance can also potentially explain why Finland-Swedish staff have a higher proportion of interactions with no address. A similar tendency to avoid addressing interlocutors directly can be found in consultations with Finnish-speaking participants (Lappalainen 2006, 2015). As discussed by Yli-Vakkuri (2005) evasiveness of this kind is typical of address practices in Finland more generally. The reasons for the evasiveness are twofold. On the one hand, not being intrusive is an important and salient feature in Finnish culture (Isosävi 2016). On the other hand, the unstable nature of the address system in Finland, where both $\mathrm{T}$ and $\mathrm{V}$ address can be received as either polite, neutral or impolite, favours the use of constructions without address as well as variation in $\mathrm{T} / \mathrm{V}$ address among individuals who make different choices when positioning themselves, for example, in service encounters.

\section{References}

Ahlgren, Perry. 1978. Tilltalsordet ni: Dess semantik och användning $i$ historiskt perspektiv [The address word ni. Its semantics and use in a historical persepctive]. Uppsala: Almqvist \& Wiksell.

Brown, Roger. and Gilman, Albert. 1960. "The pronouns of power and solidarity." In Style in Language, ed. by T. A. Sebeok, 253-276. Cambridge MA: MIT Press.

Clark, Herbert, H. 1996. Using Language. Cambridge: Cambridge University Press.

Clyne, Michael. 1992 (ed). Pluricentric Languages: Differing norms in different nations. Berlin: Mouton de Gruyter.

Clyne, Michael, Catrin Norrby, and Jane Warren. 2009. Language and Human Relations: Styles of Address in Contemporary Language Cambridge: Cambridge University Press.

Couper-Kuhlen, Elizabeth \& Margret Selting. 2001. "Introducing Interactional Linguistics." In Studies in Interactional Linguistics, ed. by M. Selting, and E. Couper-Kuhlen,1-23. Amsterdam: John Benjamins 
Fremer, Maria. 2015. "At the Cinema: The Swedish 'du- reform' in Advertising Films." In Address Practice as Social Action: European Perspectives, ed. by C. Norrby \& C. Wide, 54-74. Basingstoke: Palgrave Macmillan.

Isosävi, Johanna. 2016. "Politeness in Finland in the eyes of the French." Paper presented at the Seminar Politeness across Languages and Cultures. Helsinki, 9 September, 2016.

Kern, Friederike \& Selting, Margret. 2012. "Conversation Analysis and Interactional Linguistics." In The Encyclopedia of Applied Linguistics, ed. by C. Chapelle. Wiley Online Library.

Lappalainen, Hanna. 2006. "Mie vai mää, sinä vai te? Virkailijoiden kielelliset valinnat itseen ja vastaanottajaan viitattaessa [I or $m e$, you.SG or you.PL: The linguistic choices made by staff when referring to themselves and the recipients]." In Arjen asiointia: Keskusteluja Kelan tiskin äärellä [Everyday service encounters: Discussions at the counter at the Social Insurance Institute of Finland], ed. byt M-L. Sorjonen \& L. Raevaara, 241-284. Helsinki: Suomalaisen Kirjallisuuden Seura.

Lappalainen, Hanna. 2015. "Sinä vai te vai sekä että? Puhuttelukäytännöt suomen kielessä [You.SG or you.PL or both? Address conventions in Finnish]." Saako sinutella vai täytyykö teititellä? Tutkimuksia eurooppalaisten kielten puhuttelukäytännöistä [Is it allowed to use T address or do you have to use V address? Studies of address practices in European languages], ed. by J. Isosävi \& H. Lappalainen, 72-104. Helsinki: Suomalaisen Kirjallisuuden Seura.

Lassus, Jannika. 2010. Betydelser i barnfamiljsbroschyrer. Systemiskfunktionell analys av den tänkta läsaren och institutionen [Meanings in brochures to families with children. A system-functional analysis of the reader and the institution]. Ph.D. Dissertation. Helsinki: University of Helsinki.

Liebkind, Karmela, Tom Moring, and Marika Tandefelt (eds). 2007. The Swedish-speaking Finns. International Journal of the Sociology of Language 187/188 (special issue).

Lindström, Jan. 2008. Tur och ordning. Introduktion till svensk samtalsgrammatik [Take your turn. Introduction to Swedish interactional grammar]. Stockholm: Norstedts.

Lindström, Jan \& Wide, Camilla. Forthc. "Vid biljettluckan. Formell och pragmatisk variation $\mathrm{i}$ kundernas ärendepresentation i servicesamtal på svenska" [At the counter. Formal and pragmatic variation in presentations of the reason for visit in service encounters in Swedish]. To be published in the conference proceedings of Svenskans beskrivning 35 . Gothenburg.

Mårtensson, Eva. 1986. "Det nya niandet" [The new V address]. In Nordlund 10, 35-79. Lund: Department of Scandinavian Languages. 
Norrby, Catrin, Camilla Wide, Jenny Nilsson, and Jan Lindström. 2015a. "Address and interpersonal relationships in Finland-Swedish and Sweden-Swedish service encounters." In Address Practice as Social Action. European Perspectives, ed. by C. Norrby \& C. Wide, 75-96. Basingstoke: Palgrave Macmillan.

Norrby, Catrin, Camilla Wide, Jenny Nilsson, and Jan Lindström. 2015b. "Interpersonal relationships in medical consultations. Comparing Sweden-Swedish and Finland-Swedish Address Practices." Journal of Pragmatics 84:121-138.

Ochs, Elinor, Emanuel A. Schegloff, and Sandra A. Thompson (eds). 1996. Grammar and Interaction. Cambridge: Cambridge University Press.

Parkvall, Mikael. 2016. Sveriges språk i siffror. Vilka språk talas och av hur många? [Sweden's languages in numbers. Which languages are spoken and by how many?]. Stockholm: Morfem.

Reuter, Mikael. 1992. "Swedish as a pluricentric language." In Pluricentric Languages. Different Norms in Different Nations, ed. by M. Clyne, 111-116. Berlin: Mouton de Gruyter.

Saari, Mirja. 2012. "The development of Finnish into a national language." In Standard Languages and Multilingualism in European History, ed. by M. Hüning, U. Vogl, and O. Moliner, 179-204. Amsterdam: John Benjamins.

Schneider, Klaus. 2010. "Variational pragmatics." In Variation and Change. Pragmatic Perspectives, ed. by M. Fried, J.-O. Östman, and J. Verschueren, 239-267. Amsterdam: John Benjamins.

Schneider, Klaus, and Anne Barron. 2008. Variational Pragmatics: A Focus on Regional Varieties in Pluricentric Languages. Amsterdam: John Benjamins.

Silverstein, Michael. 2003. "Indexical order and the dialectics of sociolinguistic life." Language and Communication 23:193-229.

Wide, Camilla, and Benjamin Lyngfelt. 2009. "Svenskan i Finland, grammatiken och konstruktionerna." In Konstruktioner $i$ finlandssvensk syntax. Skriftspråk, samtal och dialekter, ed. by C. Wide, and B. Lyngfelt. Helsinki: Svenska litteratursällskapet i Finland.

Yli-Vakkuri, Valma. 2005. 'Politeness in Finland: Evasion at all cost'. In Politeness in Europe, ed. by L. Hickey and M. Stewart (eds)

Clevedon: Multilingual Matters, pp. 189-202.

\section{Transcription conventions and glossing symbols}

$\begin{array}{ll}{[} & \text { point when overlapping talk begins } \\ ] & \text { point when overlapping talk stops } \\ \dot{\delta} & \text { slightly rising intonation } \\ \text { wo- } & \text { audible cut-off } \\ \text { wo+ord } & \text { legato pronunciation }\end{array}$




$\begin{array}{ll}\begin{array}{l}\text { wo:rd } \\ { }^{\text {oword }}{ }^{\text {o }}\end{array} & \begin{array}{l}\text { lengthening of the sound } \\ \text { quiet or soft voice } \\ \text { \#word\# }\end{array} \\ \text { creaky voice } \\ \text { >word< } & \text { produced with faster pace } \\ \text { <word> } & \text { produced with a slower pace } \\ \text { (word) } & \text { uncertain transcription } \\ ((\text { word })) & \text { meta comment } \\ (0.5) & \text { silence measured in tenths of a second } \\ (.) & \text { micro pause, less than } 2 \text { seconds } \\ \text { mt } & \text { click (e.g. from smacking one's lips) } \\ . h & \text { audible inhalation (the more h's, the more aspiration) } \\ \text { VOC } & \text { vocative } \\ \text { T } & \text { T address } \\ \text { V } & \text { V address } \\ \text { PL } & \text { plural }\end{array}$

